\title{
An Analysis of the Students' Needs and their Speaking Proficiency in Designing Instructional Materials
}

\author{
Muhammad Basri D.1 \\ Hariratul Jannah² \\ Andi Tenri Ampa ${ }^{3}$

\begin{abstract}
${ }^{1}$ Department of English, Faculty of Letters, UMI Makassar, South Sulawesi, Indonesia 2Department of English, Faculty of Letters, UMI Makassar, South Sulawesi, Indonesia ${ }^{3}$ Department of English Education, Faculty of Teachers Training and Education, Unismuh Makassar, South Sulawesi, Indonesia E-mail: basri_fs@yahoo.com
\end{abstract}

\author{
Doi:10.5901/mjss.2016.v7n4p
}

Abstract

The article was the results of empirical work to analyse the students' needs and their proficiency for instructional materials. To produce such materials also required intensive processes from one step to another. Hence, the research aimed to know: (1) the extent of relations between needs and proficiency and (2) the interrelations of pronunciation, structure, and vocabulary of the English speaking skills. In collecting data, the questionnaire items had been used. The data were analysed by using a statistic analysis. The results showed that the intention in designing the instructional materials required the analysis of the students' needs for the English speaking skills. Thus, the research products were hopefully fruitful to develop the English speaking skills for the English department students.

Keywords: Needs, Proficiency, Instructional Materials

\section{Introduction}

The instuctional materials for the English speaking skills will be equipped with multimedia, so that the materials contain texts as the printed materials, audio-visual aids, and a number of varied exercises that have relations with the themes of the topics of interest. The texts may contain monologues and dialogues. The products are certainly expected to solve the students' problems to learn the English speaking skills. Besides, the products can motivate them to learn in order to improve their English proficiency.

To attain the given purposes, the requirement of need analysis to design instructional materials is really essential. The English speaking materials which are equipped with multimedia will provide artistic and natural values because the object images will be powered by the natural surroundings. It is remarked that education should be carried out in the natural environment that is clean, quiet, pleasant and fresh, so that they grow as good human beings.

The teaching and learning process of English needs the instructional materials. The instructional materials are necessary to develop for producing good products. Hence, good products that can motivate the students to learn should undergo the process of need analysis. Need analysis can be depicted as the underpinning to do next phases in designing the instructional materials. For example, Heinich, et al. (1996) with ASSURE model put 'analyze' as the first phase in developing the instructional materials, and then it is followed by the other phases (state, select, utilize, require, and evaluate).

The use of instrunctional materials will overcome the students' problems in learning the English speaking skills. The products of instructional materials include the objectives that should be achieved in every topic of the lesson. These objectives become the target, so that both lecturers and students have strong motivation to learn for the attainment of the target. The products also include directions for lecturer to present the lessons and directions for students in doing the learning activities for the speaking skills.

The development of the English speaking skills can be seen from various aspects, for examples: the pronunciation of phonemes, the correct choice of words in context, the accurate use of grammars, and the use of suprasegmental phonemes of the language. These aspects are included as the language aspects that should be developed in order to master the English speaking skills. For the purpose of making good communication, there are components that are also 
very essential to notice. These components are setting, participants, ends, act sequence, key, instrumentalities, norms, and gender (Chaer and Agustina, 1995; Kernan, 1971; Ibrahim, 1994).

The problem of the research copes with the students' needs and these are formulated in the research questions. Thus, the research questions are refered to the students' needs and their proficiency that ask about (1) the extent of relations between needs and proficiency and (2) the interrelations of pronunciation, structure, and vocabulary of the English speaking skills.

\section{Literature Review}

\subsection{Learning and Instructional Materials}

The word 'learning' is defined as wide knowledge gained by careful study (Hornby, 1980). Thus, learning is the process of obtaining or receiving knowledge and skills about the things. This learning can be done through sight, hearing, feeling and touch. Learning takes place in any environment. Learning takes place in the family and society, both informal and formal settings. Most people associate learning as a formal education that happens in schools.

Instructional materials are substantive and pedagogical component that can be observed. Teaching materials potentially determine the quality of language input and language training during the learning process in the classroom (Ampa, et al., 2013). In choosing the instructional materials, there are three principles that are required according to Sudrajat (2008), namely: (1) relevance, (2) consistency, and (3) adequacy. The relevance principle means that instructional materials have relevance to the attainable standard of competence and the basic competencies. Consistency principle means the appropriate attitudes between instructional materials and the basic competencies that should be controlled by the students. Sufficiency principle means that the materials being taught should be sufficient to help them master the basic competencies.

\subsection{The Development of Language skills}

There are various stages that can be done in the development of language skills. Brandywine, Rubenstein, and Katie (2013) in their article entitled 'How to Develop Good Communication Skills' describe clearly about the stages in the development of communication skills, comprising: understanding the basic communication skills, engaging your audience, using your words, and using your voice. Burkart (2004) states that speaking skills involve three areas of knowledge, i.e.: mechanics, functions, and social and cultural rules and norms.

Richard (1990) develops the activities of speaking skills for the class into three functions, namely the function of interaction, the function of transaction, and the function of performance. Interaction refers to what we usually mean by conversation and describe interaction that serves the main social functions, such as 'hello' when people meet because they want to be friendly and establish a comfort zone of interaction with others. Transaction refers to a situation where the focus is what is said or done. And, performance refers to the volume of activities carried out within the allotted time.

\subsection{Previous Studies}

Based on the research results, an article about the English language proficiency development through a model of crossenvironment approach is written by Basri (2010) who states that the English language proficiency is determined by the dynamics in the use of language at the level of communication. It has been concluded that the students of English department can improve their English proficiency, including accuracy, fluency, and concept. Besides, they can also gain positive attitudes and strong motivations.

Ginting, et al. (2012) conduct the development of research with the method of research and development of Borg and Gall (1983) and modified by the experimental research carried out in two steps. The first step of this research used a descriptive method to get the material and design of teaching materials course of English for Tourism based on the local needs. Furthermore, Ginting, et al. (2012) clearly outline the development of research results. The results show that the teaching materials of ESP-Tourism with the base of local needs for the areas of Lake Toba are relatively varied and diverse. The diversity of teaching materials makes the specific characteristics of the area that are not possessed by the other areas. The materials can be grouped into two main parts: the topics of talk used for communication and tourist visits. And, the second materials are concerned with function or theme of language used by tour players, for examples how to do a conversation, how to great someone for the first time, how to offer something, how to ask for help, how to say agreement or disagreement, and how to say 'thank you', and so forth. 
Baharuddin (2010) states that the frequent problem in the learning process is the availability of sufficient instructional materials. However, the instructional materials are not fully developed in accordance with the students' needs and their characteristics, so that the students are not quite motivated and encouraged to increase their knowledge through the available instructional materials. Thus, the developer has attempted to develop the instructional materials based on the students' needs and characteristics for class X Semester 1 in State Senior High School 4, Berau. In this connection, Basri (2015) has concluded that in designing the instructional materials the analysis of the students' needs and their proficiency of speaking skills are essential to do based on the procedures of the model used.

\section{Materials and Methods}

The type of this research was Research and Development which potentially produced printed materials for a course of the English speaking skills. The primary step of this research design was to analyze the students' needs and their proficiency of the English speaking skills through Levene's test for equality of variances and the t-test for equality of means in order to know the extent of relations between needs and proficiency. Further, the students' needs and their proficiency included pronunciation, structure, and vocabulary. Those components were tested by using Test of Normality with Mann-Whitney Test for finding the interrelations of pronunciation, structure, and vocabulary of the English speaking skills.

The research instrument was the use of questionnaire items that covered the above issues for the analysis of the students' needs and and their proficiency. The form of questionnaire items was indicated by the levels of needs from the very important to very unimportant points to be chosen. And, for the English proficiency, the students decided their levels based on their own perceptions. The type of data was primary-quantitative. The data had been gathered from the second semester students of English department, Faculty of Letters, UMI Makassar, South Sulawesi, Indonesia. A number of students consisted of 40 persons. Thus, those students took English as their major subjects. The data were identified, organized, calculated, classified, and evaluated. The analysis was done through a statistical analysis.

\section{Results and Discussion}

The research findings refer to research questions and objectives of the study. The discussions are also provided for the findings with the coherent links about the focuses on the research variables.

\subsection{The Variances of Needs and Proficiency}

The analysis of the students' needs and their proficiency had been done through the procees of SPSS work. Table 1 below shows Levene's test for equality of variances and the t-test for equality of means.

Table 1: The Variances of Needs and Proficiency

Independent Samples Test

\begin{tabular}{|c|c|c|c|c|c|c|c|c|c|c|}
\hline & \multicolumn{2}{|c|}{$\begin{array}{l}\text { Levene's Test } \\
\text { for Equality } \\
\text { of Variances }\end{array}$} & \multicolumn{7}{|c|}{ t-test for Equality of Means } \\
\hline & & \multirow[t]{2}{*}{$\mathrm{F}$} & \multirow[t]{2}{*}{ Sig. } & \multirow[t]{2}{*}{$\mathrm{t}$} & \multirow[t]{2}{*}{ df } & \multirow{2}{*}{$\begin{array}{c}\text { Sig. } \\
\text { (2-tailed) }\end{array}$} & \multirow{2}{*}{$\begin{array}{c}\text { Mean } \\
\text { Difference }\end{array}$} & \multirow{2}{*}{$\begin{array}{l}\text { Std. Error } \\
\text { Difference }\end{array}$} & \multicolumn{2}{|c|}{$\begin{array}{c}95 \% \text { Confidence Interval } \\
\text { of the Difference }\end{array}$} \\
\hline & & & & & & & & & Lower & Upper \\
\hline \multirow{2}{*}{ Need } & $\begin{array}{l}\text { Equal variances } \\
\text { Assumed }\end{array}$ & \multirow[t]{2}{*}{.045} & \multirow[t]{2}{*}{.833} & \multirow[b]{2}{*}{-3.9} & \multirow{2}{*}{\begin{tabular}{c|c}
0 & 78 \\
0 & 77.100
\end{tabular}} & \multirow[t]{2}{*}{.000} & \multirow{2}{*}{$\begin{array}{l}-.8625 \\
-.8625\end{array}$} & \multirow{2}{*}{$\begin{array}{l}.2178 \\
.2178\end{array}$} & \multirow{2}{*}{$\begin{array}{l}-1.2961 \\
-1.2962\end{array}$} & \multirow{2}{*}{$\begin{array}{l}-.4289 \\
-.4288\end{array}$} \\
\hline & $\begin{array}{l}\text { Equal variances } \\
\text { not assumed }\end{array}$ & & & & & & & & & \\
\hline \multirow{2}{*}{ Proficiency } & $\begin{array}{l}\text { Equal variances } \\
\text { assumed }\end{array}$ & \multirow[t]{2}{*}{4.584} & \multirow[t]{2}{*}{.035} & \multirow{2}{*}{$\begin{array}{l}-.846 \\
-.846\end{array}$} & \multirow{2}{*}{$\begin{array}{c}78 \\
75.540\end{array}$} & \multirow{2}{*}{$\begin{array}{l}.400 \\
.400\end{array}$} & \multirow{2}{*}{$\begin{array}{l}-.1500 \\
-.1500\end{array}$} & \multirow{2}{*}{$\begin{array}{l}.1773 \\
.1773\end{array}$} & \multirow{2}{*}{$\begin{array}{l}-.5030 \\
-.5032\end{array}$} & \multirow{2}{*}{$\begin{array}{l}.2030 \\
.2032\end{array}$} \\
\hline & $\begin{array}{l}\text { Equal variances } \\
\text { not assumed }\end{array}$ & & & & & & & & & \\
\hline
\end{tabular}


Based on the Independent Samples Test table for needs, the value results of Levene's test for homogeneity can be said that the data are homogeneous $(0,833>0,05)$. Because of the homogeneity, the first line is used, i.e. the value of t-count is $-3,960$ on $\mathrm{dF} 78$. By choosing the t-test for equality of means table above, where the value of Sig. (2-tailed) is 0,000 . The $p$ value is $0,000<0,05$. This case means that there are differences among the pronunciation, structure, and vocabulary on the degree of $5 \%$. These differences are caused by the various ideas possessed by the students in learning the English speaking skills. Some of them want to increase their vocabulary earliear than the others and some others want to improve their pronunciation and or their structure earlier than the other.

Based on the Independent Samples Test table for proficiency, the value results of Levene's test for homogeneity can be said that the data are not homogeneous $(0,035<0,05)$. Because of non-homogeneity, the second line is used, i.e. the value of t-count is $-0,846$ on $\mathrm{dF} 75,54$. By choosing the t-test for equality of means table above, where the value of Sig. (2-tailed) is 0,400 . The $p$ value is $0,400>0,05$. This case means that there is not any difference among the pronunciation, structure, and vocabulary on the degree of $5 \%$. These indifferences are caused by the facts that these motor-receptive skills should be mastered well for attaining the English speaking skills. These three components cannot be separated in developing the progress of English proficiency.

\subsection{Test of Normality}

Tables 2 and 3 below show the results of test of normality. The purpose of this test is to show the significant difference between needs and proficiency for pronunciation, structure, and vocabulary.

Table 2: Case Processing Summary

\begin{tabular}{|c|c|c|c|c|c|c|c|}
\hline & \multirow{3}{*}{ Need } & \multicolumn{6}{|c|}{ Cases } \\
\hline & & \multicolumn{2}{|c|}{ Valid } & \multicolumn{2}{|c|}{ Missing } & \multicolumn{2}{|c|}{ Total } \\
\hline & & $\mathrm{N}$ & Percent & $\mathrm{N}$ & Percent & $\mathrm{N}$ & Percent \\
\hline \multirow{3}{*}{ Proficiency } & Pronunciation & 40 & $100.0 \%$ & 0 & $.0 \%$ & 40 & $100.0 \%$ \\
\hline & Structure & 40 & $100.0 \%$ & 0 & $.0 \%$ & 40 & $100.0 \%$ \\
\hline & Vocabulary & 40 & $100.0 \%$ & 0 & $.0 \%$ & 40 & $100.0 \%$ \\
\hline
\end{tabular}

Table 3: Tests of Normality

\begin{tabular}{|c|c|c|c|c|c|c|c|}
\hline \multicolumn{4}{c|}{ Tests of Normality } \\
\hline \multirow{2}{*}{ Need } & \multicolumn{3}{|c|}{ Kolmogorov-Smirnova } & \multicolumn{3}{c|}{ Shapiro-Wilk } \\
\cline { 3 - 8 } & Statistic & df & Sig. & Statistic & df & Sig. \\
\hline \multirow{3}{*}{ Proficiency } & Pronunciation & .135 & 40 & .065 & .945 & 40 & .050 \\
& Structure & .222 & 40 & .000 & .862 & 40 & .000 \\
& Vocabulary & .288 & 40 & .000 & .694 & 40 & .000 \\
\hline
\end{tabular}

Lilliefors Significance Correction

The test of normality table above indicates that the results of Kolmogrov-Sminorv test and Shapiro Wilk test for pronunciation refer to the value of $\mathrm{P}(\mathrm{sig})>0,05$, meaning that the data have distributed normally, but for structure and vocabulary the result refers to the value of sig $<0,05$ that means that the data do not distribute normally.

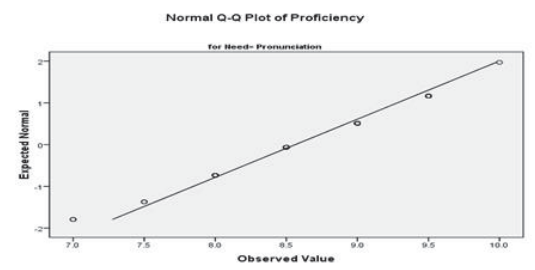

Figure 1: Observed Value of Pronunciation 


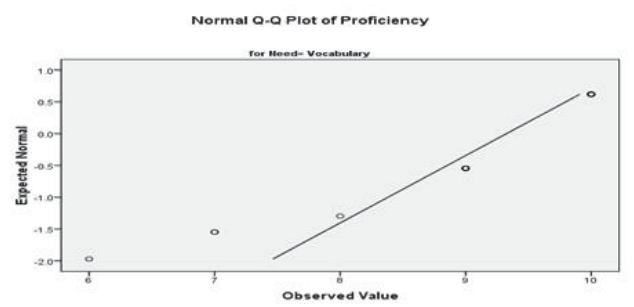

Figure 2: Observed Value of Structure

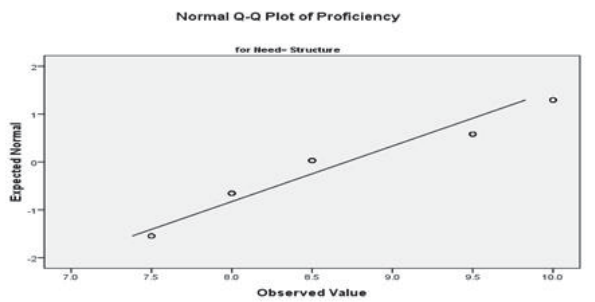

Figure 3: Observed Value of Vocabulary

The figures above show the data for pronunciation distribute normally. It is indicated by the plots that follow the fit line, but for structure and vocabulary the data do not distribute normally because the plots do not follow the fit lines. The following is the use of Mann-Whitney Test for finding the interrelations of pronunciation, structure, and vocabulary of the English speaking skills.

\section{a. Pronunciation-Structure}

Table 4: Ranks of Pronunciation-Structure

Ranks

\begin{tabular}{|c|c|c|c|c|}
\hline & Need & $\mathrm{N}$ & Mean Rank & Sum of Ranks \\
\hline \multirow{3}{*}{ Need } & Pronunciation & 40 & 30.96 & 1238.50 \\
\hline & Structure & 40 & 50.04 & 2001.50 \\
\hline & Total & 80 & & \\
\hline \multirow{3}{*}{ Proficiency } & Pronunciation & 40 & 39.21 & 1568.50 \\
\hline & Structure & 40 & 41.79 & 1671.50 \\
\hline & Total & 80 & & \\
\hline
\end{tabular}

Table 5: Statistic Test

\begin{tabular}{|c|c|c|}
\hline \multicolumn{3}{|c|}{ Statistic Test ${ }^{a}$} \\
\hline & Need & Proficiency \\
\hline Mann-Whitney U & 418.500 & 748.500 \\
\hline Wilcoxon W & 1.238E3 & 1568.500 \\
\hline Z & -3.745 & -.507 \\
\hline Asymp. Sig. (2-tailed) & .000 & .612 \\
\hline
\end{tabular}

Grouping Variable: Need

On the rank output, it is known that the mean of pronunciation is different from the mean of structure both for the students' needs and their proficiency, where the mean of structure is greater than that of pronunciation. Based on the 
result of value of Mann-Whitney $U$ test, it can be seen on the output of Statistic Test, where the value of needs by the $Z$ test of statistic, i.e. $-3,745$ and sig.2-tailed, that is $0,000<0,05$. Therefore, the result of statistic test for significance states that the hypothesis is accepted, meaning that there is a difference beween pronunciation and structure. But for proficiency, the value of $Z$ test is $-0,507$ and sig.2-tailed, that is $0,612>0,05$. Therefore, the result of statistic test for significance states that the hypothesis is rejected, meaning that there is an indifference between pronunciation and structure.

b. Pronunciation-Vocabulary

Table 6: Ranks of Pronunciation-Vocabulary

\begin{tabular}{|ll|c|c|c|}
\hline \multicolumn{4}{|c|}{ Ranks } \\
\hline \multirow{4}{*}{ Need } & Need & Mean Rank & Sum of Ranks \\
\hline \multirow{3}{*}{ Proficiency } & Pronunciation & 40 & 40.00 & 1600.00 \\
& Vocabulary & 40 & 41.00 & 1640.00 \\
& Total & 80 & & \\
& Pronunciation & 40 & 28.99 & 1159.50 \\
& Vocabulary & 40 & 52.01 & 2080.50 \\
& Total & 80 & & \\
\hline
\end{tabular}

Table 7: Statistic Test

\begin{tabular}{|l|c|c|}
\hline & Need & Proficiency \\
\hline Mann-Whitney U & 780.000 & 339.500 \\
Wilcoxon W & $1.600 \mathrm{E} 3$ & 1159.500 \\
Z & -.201 & -4.546 \\
Asymp. Sig. (2-tailed) & .841 & .000 \\
\hline
\end{tabular}

Grouping Variable: Need

On the rank output, it is known that the mean of pronunciation is different from the mean of vocabulary both for the students' needs and their proficiency, where the mean of vocabulary is greater than that of pronunciation. Based on the result of value of Mann-Whitney $U$ test, it can be seen on the output of Statistic Test, where the value of needs by the $Z$ test of statistic, i.e. $-0,201$ and sig.2-tailed, that is 0,841>0,05. Therefore, the result of statistic test for significance states that the hypothesis is rejected, meaning that there is an indifference beween pronunciation and vocabulary. But for proficiency, the value of $Z$ test is $-4,546$ and sig.2-tailed, that is $0,000<0,05$. Therefore, the result of statistic test for significance states that the hypothesis is accepted, meaning that there is a difference between pronunciation and vocabulary.

\section{c. Structure-Vocabulary}

Table 8: Ranks of Structure -Vocabulary

Ranks

\begin{tabular}{|ll|c|c|c|}
\hline \multirow{2}{*}{ Need } & Need & N & Mean Rank & Sum of Ranks \\
\hline \multirow{4}{*}{ Structure } & 40 & 49.71 & 1988.50 \\
& Vocabulary & 40 & 31.29 & 1251.50 \\
\hline \multirow{3}{*}{ Proficiency } & Total & 80 & & \\
& Structure & 40 & 31.71 & 1268.50 \\
& Vocabulary & 40 & 49.29 & 1971.50 \\
& Total & 80 & & \\
\hline
\end{tabular}


Table 9: Statistic Test

\begin{tabular}{|c|c|c|}
\hline \multicolumn{3}{|c|}{ Statistic Testa } \\
\hline & Need & Proficiency \\
\hline Mann-Whitney U & 431.500 & 448.500 \\
\hline Wilcoxon W & $1.252 \mathrm{E} 3$ & 1268.500 \\
\hline Z & -3.628 & -3.482 \\
\hline Asymp. Sig. (2-tailed) & .000 & .000 \\
\hline
\end{tabular}

Grouping Variable: Need

On the rank output, it is known that the mean of structure is different from the mean of vocabulary both for the students' needs and their proficiency, where the mean of structure is greater than that of vocabulary. Based on the result of value of Mann-Whitney $U$ test, it can be seen on the output of Statistic Test, where the value of needs by the $Z$ test of statistic, i.e. $-3,628$ and sig.2-tailed, that is $0,000<0,05$. Therefore, the result of statistic test for significance states that the hypothesis is accepted, meaning that there is a difference beween structure and vocabulary. But for proficiency, the value of $Z$ test is $-3,482$ and sig.2-tailed, that is $0,000<0,05$. Therefore, the result of statistic test for significance states that the hypothesis is accepted, meaning that there is a difference between structure and vocabulary.

\section{Conclusion}

The primary step of the research design was to analyze the students' needs and their proficiency attainment of the English speaking skills. The results of this analysis indicate that the students' needs of motor-receptive skills are greater than their English proficiency. There is a significant difference between the students' needs of pronunciation, structure, and vocabulary and their proficiency of these three aspects. These issues can determine the quality of instructional materials. So, the design of instructional materials should refer to the students' needs and their English proficiency.

\section{Acknowledgements}

The research received a grant from Directoriate General of Higher Education, Ministry of Research and Technology, Indonesia.

\section{References}

Ampa, A. T, Basri, D. M, and Andriani, A. A. (2013). The Development of Contextual Learning Materials for the English Speaking Speaking Skills. International Journal of Education and Research. 1 (9): 1-10.

Baharuddin, A. (2010). Pengembangan bahan ajar mata pelajaran bahasa Inggris bermedia interaktif dengan model Addie (The development of teaching materials on interactive media with Addie mode/). Retrieved from http:/library.um.ac.id/free-contents/ download/pub/ pub.php/44767.pdf.

Basri, D. M. (2010). Model Pengembangan Profisiensi Berbahasa Inggris melalui Pendekatan Lintas Lingkungan (The Development Model of English Speaking Proficiency through Environmental Cross Approach) (pp. 606-612) Yokyakarta: Penerbit Ombak.

Basri, D. M. (2015). Perancangan Prototipe Bahan Ajar Keterampilan Berbicara dalam Bahasalnggris (The Prototype Design of Teaching Material for the Speaking Skills in English): Proceeding. Makassar: LPPM Universitas Bosowa Makassar. pp.1-7.

Brandywine, B. R. and Katie R. (2013). How to Develop Good Communication Skills. Retrieved from http://www.wikihow.com/Develop-GoodCommunication-Skills.

Burkart, G. S. (2004). Spoken language: What it is and how to teach it. Washington, DC: The National Capital Language Resource Center.

Chaer, A. and Agustina, L. (1995). Sosiolinguistik: Suatu Pengantar. (Sociolinguistics: An Introduction). Jakarta: Rineka Cipta.

Ginting, et al. (2012). Pengembangan Bahan Ajar Matakuliah Bahasa Ingggris Pariwisata Berbasiskan Kebutuhan Lokal. igilib.unimed.ac.id/UNIMED-Research-342008/22005

Heinich, Molenda, Russell, and Smaldino. (1999). ASSURE Model. Retrieved from http://www.mscd.edu/ act2/ course construct/ assure.html.

Hornby, A S. (1980). Oxford Advanced Learner's Ditionary of Current English. Oxford: Oxford University Press.

Ibrahim, A. S. (1994). Panduan Penelitian Etnografi Komunikasi (Guide of Communication Ethnographic Research). Surabaya-Indonesia: Usaha Nasional.

Kernan, C. M. (1971). Language Behavior in a Black Urban Community. Berkeley: University of California.

Richard, J. C. (1990). Developing Speaking Activities: From Theory to Practice. Retrieved from http://www. professorjackrichards.com/pdfs/developing-classroom-speaking.

Sudrajat. (2008). Konsep Pengembangan Bahan Ajar (Concepts of Instructional Materials Development). www.wordpress.com/ 2008/03/ 04/ konsep-pengembangan-bahan-ajar-2. 